\title{
Longitudinal variation in algal symbionts (zooxanthellae) from the Indian Ocean zoanthid Palythoa caesia
}

\author{
W. J. Burnett* \\ Department of Marine Science and Coastal Management, Ridley Building, University of Newcastle upon Tyne, \\ Newcastle NE1 7RU, United Kingdom
}

\begin{abstract}
Single-celled, symbiotic, dinoflagellate algae known as zooxanthellae form associations with many shallow-water tropical marine invertebrates. Local ecological factors, particularly light levels, are known to influence algal type and distribution within hosts. Here I investigate whether biogeographic factors are similarly important in a convenient model, the zoanthid Palythoa caesia (Dana, 1846). Algal genotypes from P. caesia specimens from the eastern and western Indian Ocean were determined by restriction analysis and sequencing of the small subunit RNA gene, following PCR amplification with algal-specific primers. RFLP results indicate 2 common algal genotypes in the east, but only a single genotype in the west. Results from sequencing suggest further geographic patterning, with restricted geographic distribution of clades from the Seychelles, Sulawesi and Thailand.
\end{abstract}

KEY WORDS: Zooxanthellae $\cdot$ Palythoa caesia $\cdot$ Biodiversity $\cdot$ RFLP

\section{INTRODUCTION}

Zooxanthellae are the golden, brown or yellow unicellular algae that form symbiotic relationships with a wide range of marine invertebrates. Among the most important of these are members of the dinoflagellate genus Symbiodinium hosted by the Scleractinia (reef building corals) and many other Cnidaria and invertebrates (Freudenthal 1962; reviews by Davies 1992, Trench 1997, Rowan 1998). Zooxanthellae play a major role in the ecology of coral reefs, through their contribution to host nutrition (Muscatine 1973, Muscatine \& Porter 1977, Davies 1984, Farrant et al. 1987, Sorokin 1991) and to the calcification process in corals (Goreau 1959, Smith \& Douglas 1987, Marshall 1996).

The shortage of unambiguous morphological features led early workers to consider Symbiodinium monospecific, as $S$. microadriaticum Freudenthal, 1962. Subsequent work using 'classical' microbiological methods, including ultrastructure and biochemistry (reviewed

${ }^{*}$ Present address: Department of Biology, St. Pauls School, Lonsdale Road, London SW13 9JT, United Kingdom.

E-mail: wjb@stpaulsschool.org.uk by Trench 1997) and the application of molecular genetic methods (reviewed by Rowan 1998) revealed a more diverse range of symbionts. Host-symbiont relationships were initially believed to be highly specific; however, further work revealed not only the occurrence of multiple strains within hosts, but that local environmental conditions drove ecological zonation in the relative abundance of different algal strains among colonies (Rowan \& Knowlton 1995) and even over the surface of individual host colonies (Rowan et al. 1997) in response to differing light levels. Ecophysiological plasticity of individual algal strains is limited (Bythell et al. 1997), but multiple strains may provide a degree of flexibility to host:symbiont associations. In corals at least, zooxanthella diversity provides a mechanism for adaptation to changing environmental conditions (Buddemeier \& Fautin 1993, Rowan et al. 1997). As a consequence, regional differences in zooxanthella diversity may be important (Baker \& Rowan 1997).

There are currently rather little published data on broad-scale biogeographic patterns in zooxanthellae associated with any taxa. Rowan \& Powers (1991) sampled the same taxa from multiple locations, but geographic variation was not their prime concern and 
sample sizes were too small to draw strong conclusions in this regard. Baker \& Rowan (1997) showed significantly less diversity in coral-associated zooxanthellae from the eastern Pacific than in the Caribbean, but since there are no species common to these 2 areas they studied different hosts in each. Baillie et al. (2000) demonstrated that zooxanthellae isolated from giant clams were similar over a wide latidudinal range in the western Pacific, from the Great Barrier Reef to Japan, but used no more than 3 isolates per species in each locality. To date there are no published large-scale studies of geographic variation in single species with convincing sample sizes. Here, I examine patterns of zooxanthella diversity in an Indian Ocean species, the zoanthid Palythoa caesia (Dana, 1846). Specifically, I test the hypothesis that zooxanthella diversity is uniform along an east-west transect across the equatorial Indian Ocean from Indonesia to Tanzania, also taking in 2 south-western populations.

Zoanthids are an order of mostly colonial anthozoans in the subclass Hexacorallia. Their origins are obscure, although ultrastructural and molecular data indicate their closest relatives are probably the Antipatharia (Schmidt 1974, Berntson et al. 1999). Palythoa caesia is a geographically widespread zoanthid common throughout the Indian Ocean and the western Pacific (Ryland \& Muirhead 1993, Burnett et al. 1995, 1997, Burnett \& Ryland 1997, Ryland et al. 2000). Zooxanthellae in this species are environmentally transmitted, presumably after settlement and metamorphosis since neither broadcast-spawned oocytes nor larvae contain algal cells (Ryland et al. 2000). Zooxanthellae present in any one colony, therefore, reflect not only local environmental conditions and innate species preferences, but also local availability of algal strains. The results presented here show an east-west reduction in algal diversity associated with this species.

\section{MATERIALS AND METHODS}

Specimens of Palythoa caesia were collected, using SCUBA or by snorkelling, from the edges of unshaded colonies in shallow water (0 to $2 \mathrm{~m}$ deep) around Zanzibar, Seychelles, Mauritius and Indonesia during 1998 and 1999 (Table 1). Specimens from the Maldives and Rodrigues were collected from around $20 \mathrm{~m}$. Five specimens were collected from Thailand with no information about degree of shading other than that they were intertidal. A small piece of tissue (ca. $50 \mathrm{mg}$ ) from each specimen was preserved in $2 \mathrm{ml}$ of $100 \%$ ethanol in their own plastic vial. Back in the laboratory, DNA was extracted from each sample using Puregene ${ }^{\mathrm{TM}}$ kits (Gentra Ltd) using the manufacturer's suggested protocol for preserved tissue. Extracts were stored frozen prior to use. Polymerase chain reaction (PCR) was used to selectively amplify algal small subunit rRNA genes from DNA extracts using zooxanthella-specific primers (Rowan \& Powers 1991) in $50 \mu \mathrm{l}$ reactions. Residual primers were removed by precipitating PCR products in 0.6 volumes of $20 \%$ polyethylene glycol (molecular weight 8000), $2.5 \mathrm{M} \mathrm{NaCl}$ and incubating at $37^{\circ} \mathrm{C}$ for $30 \mathrm{~min}$. Precipitated PCR products were recovered by centrifugation, rinsed once in $70 \%$ ethanol, air dried and re-suspended in ultrapure water.

Symbiont type of all specimens was determined using restriction fragment length polymorphism (RFLP) (Rowan Powers 1991). PCR products were digested in a total volume of $20 \mu \mathrm{l}$ with the restriction enzyme Taq1. The entire reaction volume was loaded onto a $2 \%$ agarose/Tris-EDTA-acetate gel and run for $2 \mathrm{~h}$ at $120 \mathrm{mV} / 180 \mathrm{~mA}$ in a cooled horizontal gel rig. Gels were stained in $500 \mathrm{ml}$ of $0.5 \mathrm{\mu g} \mathrm{ml}^{-1}$ ethidium bromide solution for $20 \mathrm{~min}$, destained in tap water for $2 \mathrm{~min}$ and visualised on a UV transilluminator.

Higher resolution data were obtained by DNA sequencing PCR products from a subset of specimens, including 7 Sulawesian, 4 Balinese, 9 Maldive, 4 Thai, 6 Seychelles, 5 Mauritian and 7 Zanzibar specimens. PCR products were direct sequenced using an ABI377 automated sequencer and primer NS21 (5'-AAT ATA CGC TAT TGG AGC TGG-3') (Simon et al. 1992). Sequences were aligned by eye. A phylogeny was constructed using maximum parsimony, using the PHYLIP package (Felsenstein 1993). The aligned dataset was bootstrapped 1000 times, and nodes with greater than $70 \%$ support shown resolved in the resulting trees.

Table 1. Localities, sample numbers (n) and observed RFLP genotype frequencies of clade $\mathrm{C}$ and $\mathrm{D}$ algae $\left(f_{\mathrm{C}}\right.$ and $f_{\mathrm{D}}$, respectively). Locality numbers correspond to those used in Fig. 1

\begin{tabular}{|llrrrrr|}
\hline Locality name & Specific location & Latitude & Longitude & $\mathrm{n}$ & $f_{\mathrm{C}}$ & $f_{\mathrm{D}}$ \\
\hline NE Sulawesi & $\begin{array}{l}\text { South reef, } \\
\text { Bunaken Island }\end{array}$ & $1^{\circ} 42^{\prime} \mathrm{N}$ & $124^{\circ} 45^{\prime} \mathrm{E}$ & 49 & 34 & 15 \\
SW Sulawesi & $\begin{array}{l}\text { Samalona Island, } \\
\text { Makassar Strait }\end{array}$ & $5^{\circ} 10^{\prime} \mathrm{S}$ & $119^{\circ} 22^{\prime} \mathrm{E}$ & 12 & 9 & 3 \\
& & & & & \\
SE Sulawesi & Patch reef, Kendari Bay & $3^{\circ} 58^{\prime} \mathrm{S}$ & $122^{\circ} 45^{\prime} \mathrm{E}$ & 38 & 30 & 8 \\
S Bali & Sanur Beach & $8^{\circ} 40^{\prime} \mathrm{S}$ & $115^{\circ} 15^{\prime} \mathrm{E}$ & 20 & 15 & 5 \\
Thailand & Fringing reef, Phuket & $7^{\circ} 53^{\prime} \mathrm{N}$ & $98^{\circ} 23^{\prime} \mathrm{E}$ & 5 & 3 & 2 \\
Maldives & Malé Atoll & $4^{\circ} 27^{\prime} \mathrm{N}$ & $73^{\circ} 09^{\prime} \mathrm{E}$ & 21 & 10 & 11 \\
Seychelles & Southeast reef, & $4^{\circ} 37^{\prime} \mathrm{S}$ & $55^{\circ} 27^{\prime} \mathrm{E}$ & 35 & 35 & 0 \\
& Isle St. Anne & & & & \\
Zanzibar & Bawe Island & $6^{\circ} 10^{\prime} \mathrm{S}$ & $39^{\circ} 15^{\prime} \mathrm{E}$ & 29 & 29 & 0 \\
Rodrigues & NE reef slope & $19^{\circ} 40^{\prime} \mathrm{S}$ & $63^{\circ} 30^{\prime} \mathrm{E}$ & 13 & 13 & 0 \\
Mauritius & Blue Bay & $20^{\circ} 30^{\prime} \mathrm{S}$ & $57^{\circ} 16^{\prime} \mathrm{E}$ & 22 & 22 & 0 \\
\hline
\end{tabular}




\section{RESULTS}

RFLP

Each Palythoa caesia colony contained only a single detectable algal type during RFLP analysis. Taq1 digestion patterns revealed the presence of 2 algal genotypes within $P$. caesia, corresponding to previously published patterns C and D of Rowan \& Powers (1991), recently clarified by LaJeunesse et al. (in press; Fig. 1). Type C zooxanthellae were present in high frequency throughout the Indian Ocean, whereas type D was present in all populations east of and including the Maldives, but absent from all populations to the west (Fig. 2).

\section{Sequencing}

All the individual colonies examined showed single, unambiguous sequences, but variation was observed among individuals at all localities except Zanzibar. From 42 specimens, 424 unambiguously aligned nucleotide sites were used in phylogenetic analysis (Fig. 3). Results show the presence of 2 major clades largely corresponding to RFLP clades C and D. A single specimen with RFLP type C, Mauritius 5, clustered with type D genotypes in the sequence analysis. The tree topology shows evidence of a biogeographic segregation of variability. Within major clade D, samples from Sulawesi and Thailand both form wellsupported sub-clades, whilst Seychelles samples form a sub-clade within major clade $\mathrm{C}$. The data were inadequate to resolve robustly a large polytomy at the base of clade $\mathrm{C}$.

The disagreement on the identity of Mauritius 5 between the 2 methods (RFLP and sequencing) probably stems from the much larger number of characters used in sequence analysis. However, since the remaining 41 sequenced individuals fell into the correct RFLP clade, this result is not considered to seriously compromise the results of the RFLP analysis.

DNA sequences are available from GenBank, under the accession numbers AF 398922-398928 and AF 410390-410424

\section{DISCUSSION}

The observations presented here clearly demonstrate that, while some zooxanthella genotypes are geographically widespread, populations of west-

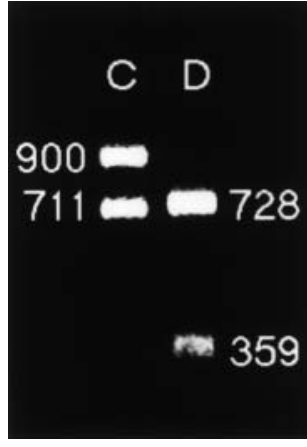

Fig. 1. Taq1 restriction fragment length patterns from type C and D zooxanthellae associated with Palythoa caesia. Fragment size is denoted in base pairs

ern Indian Ocean Palythoa caesia have different algal complements from their eastern relatives. Clades $\mathrm{C}$ and D, as defined by RFLP patterns, are both present in the east, while only clade $\mathrm{C}$ occurs in the west. Phylogenetic analysis revealed well-supported sub-clades unique to Seychelles, Sulawesi and Thailand. The geographic distribution of zooxanthella genotypes associated with $P$. caesia is clearly not homogeneous.

Since vertical transmission (infection of juveniles with symbionts from the parent) does not occur in Palythoa caesia (Ryland 1997), zooxanthellae must be drawn from a free-living environmental pool. Speciesspecific preferences may influence which algae are accepted and which rejected, but these data show that $P$. caesia commonly harbours a diverse range of algae. The failure to observe clade D symbionts in western Indian Ocean samples may reflect either an ecological difference from the east or else reduced environmental availability of this type relative to clade C.

The ecological factor believed to have the greatest influence on symbiont clade within a particular host is irradiance (Rowan \& Knowlton 1995, Rowan et al. 1997).

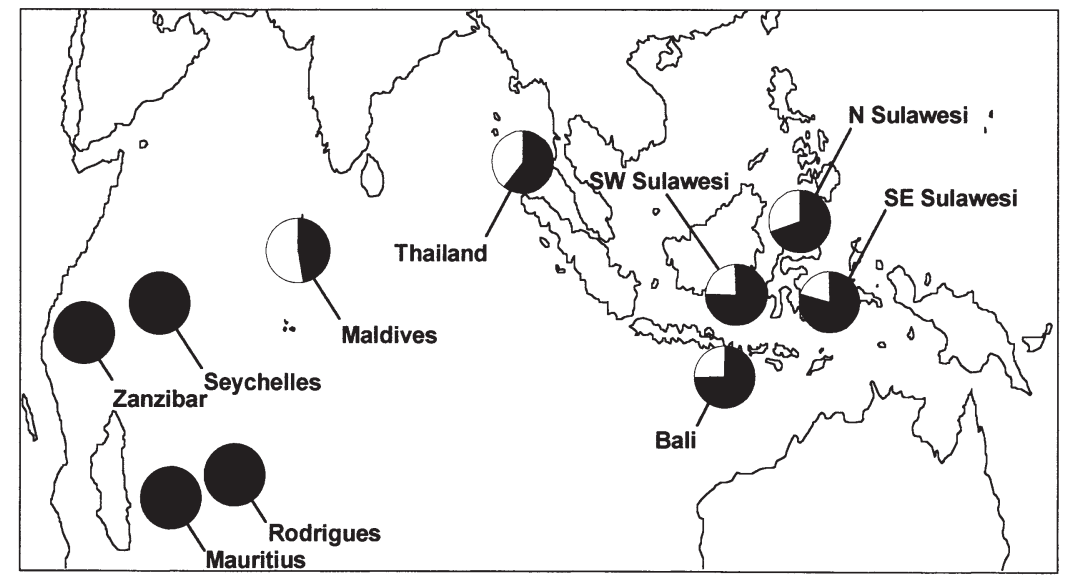

Fig. 2. Frequency distribution of zooxanthella RFLP genotypes from Palythoa caesia samples from the Indian Ocean. Within each pie diagram the frequency of type C symbionts is shown in black and type $\mathrm{D}$ in white 


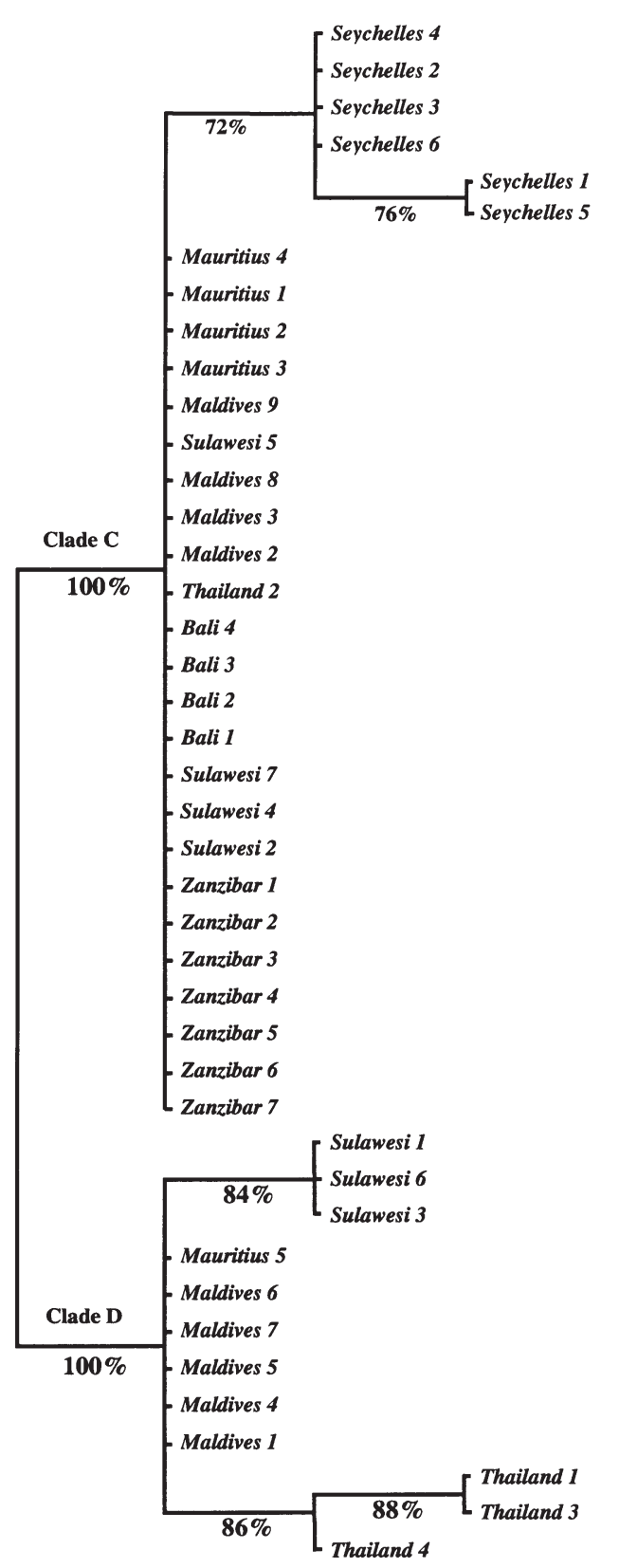

Fig. 3. Maximum parsimony phylogeny based on 424 unambiguously aligned nucleotide sites. Sequences fall into 2 major clades, corresponding to RFLP clades C and D for all specimens except Mauritius 5, which has a clade C RFLP pattern but a clade $\mathrm{D}$ sequence

However, in most cases overall light levels should be similar among samples in this study; all except 3 are at low latitudes with clear shallow water. Palythoa caesia colonies are generally small $(5$ to $10 \mathrm{~cm}$ ), flat and encrusting, so self-shading is not important. The increased incidence of type D strains in the deeper water sample from the Maldives might suggest that lower light levels favour this strain. However, D is absent from 2 high-latitude populations (Mauritius and Rodrigues). Furthermore, the Rodrigues sample was also taken in deeper, relatively turbid water and should have the lowest light levels of any sample. Ecological influences, as far as we currently understand them, do not appear to explain the observed distribution of symbiont types in P. caesia. Conversely, there are plenty of precedents for a biogeographical explanation. Many taxa show a decline in diversity with increasing distance from the central Indo-west Pacific (Veron 1986, Sheppard 1998, Briggs 1999) while others show breaks in their distributions between east and west (Harlin 1996, Randall 1998, Ridgway et al. 1998). Genetic differences within taxa have been observed over the same scales (Williams \& Benzie 1998). I conclude that the failure to observe type D symbionts in western Indian Ocean P. caesia is more likely to reflect the limits of its geographic distribution than unfavourable ecological factors.

Variation in zooxanthella diversity among geographic regions could have major implications for local communities. Zooxanthella diversity may provide hosts with a rapid mechanism for adaptation to change (Buddemeier \& Fautin 1993, Rowan et al. 1997); hence hosts in regions with depauperate floras may have few adaptive options (Baker \& Rowan 1997). It should be noted, however, that the importance of variation within rRNA defined clades remains to be determined and the link between rRNA diversity and photophysiology clarified.

These data concern only a single host species, in a restricted set of geographic regions. Further widespread sampling of diverse taxa is required in order to determine if the geographic variability observed in symbioses of Palythoa caesia and zooxanthellae is unusual or the norm.

Acknowledgements. C. Bradshaw, B. Brown, M. Callow, B. Chapman, S. Clark, P. Cornelius, M. Johnson, E. Grandcourt, M. Richmond, J. Robinson and B. Stobart provided samples or gave invaluable assistance in the field. J. Bythell, B. Brown, A. Douglas, M. Goodson, R. Rowan, S. Williams, W. Loh and 3 anonymous referees made valuable comments on the data and on various drafts of the manuscript. The work described in this paper was partially undertaken as part of the Royal Geographical Society (with IBG) - Royal Society Shoals of Capricorn Programme, western Indian Ocean, 1998 to 2001. This is Shoals Contribution No. P005. The project was funded by the University of Newcastle's Sir James Knott Fellowship.

\section{LITERATURE CITED}

Baillie BK, Belda-Baillie CA, Maruyama T (2000) Conspecifity and Indo-Pacific distribution of Symbiodinium genotypes (Dinophyceae) from giant clams. J Phycol 36: 1153-1161

Baker AC, Rowan R (1997) Diversity of symbiotic dinoflagel- 
lates (zooxanthellae) in scleractinian corals of the Caribbean and eastern Pacific. Proc 8th Int Coral Reef Symp 2: 1301-1306

Berntson EA, France SC, Mullineaux LS (1999) Phylogenetic relationships within the Class Anthozoa (Phylum Cnidaria) based on nuclear $18 \mathrm{~S}$ rDNA sequences. Mol Phylogenet Evol 13:417-433

Briggs JC (1999) Extinction and replacement in the Indo-West Pacific Ocean. J Biogeogr 26:777-783

Buddemeier RW, Fauntin DG (1993) Coral bleaching as an adaptive mechanism. Bioscience 43:320-325

Burnett WJ, Ryland JS (1997) Order Zoanthidea. In: Richmond MD (ed) A guide to the seashores of eastern Africa. Sida (Department for Research Cooperation), Stockholm, p 138-139

Burnett WJ, Benzie JAH, Beardmore JA, Ryland JS (1995) Patterns of genetic subdivision in populations of a clonal cnidarian, Zoanthus coppingeri, from the Great Barrier Reef. Mar Biol 122: 665-673

Burnett WJ, Benzie JAH, Beardmore JA, Ryland JS (1997) Zoanthids (Anthozoa, Hexacorallia) from the Great Barrier Reef and Torres Strait, Australia: systematics, evolution and a key to species. Coral Reefs 16:55-68

Bythell JC, Douglas AE, Sharp VA, Searle JB, Brown BE (1997) Algal genotype and photoacclimatory responses of the symbiotic alga Symbiodinium in natural populations of the sea anemone Anemonia viridis. Proc R Soc Lond Ser B Biol Sci 264:1277-1282

Davies PS (1984) The role of zooxanthellae in the nutritional energy-requirements of Pocillopora eydouxi. Coral Reefs 2:181-186

Davies PS (1992) Endosymbiosis in marine cnidarians. In: John DM, Hawkins SJ, Price JH (eds) Plant-animal interactions in the marine benthos. Clarendon Press, Oxford, p 511-540

Farrant PA, Borowitzka MA, Hinde R, King RJ (1987) Nutrition of the temperate Australian soft coral Capnella gaboensis. 2. The role of zooxanthellae and feeding. Mar Biol 95:575-581

Felsenstein J (1993) PHYLIP (Phylogeny Inference Package) version 3.5c. Department of Genetics, University of Washington, Seattle

Freudenthal H (1962) Symbiodinium gen nov. and Symbiodinium microadriaticum sp. nov., a zooxanthella; taxonomy, life cycle and morphology. J Protozool 9:45-52

Goreau TF (1959) The physiology of skeleton formation in corals. I. A method for measuring the rate of calcium deposition by corals under different conditions. Biol Bull 116: $59-75$

Harlin M (1996) Biogeographic patterns and the evolution of eureptantic nemerteans. Biol J Linn Soc 58:325-342

LaJeunesse TC, Pochon X, Baker AC (in press) Revision of clade nomenclature for symbiotic dinoflagellates in the genus Symbiodinium. J Phycol

Marshall AT (1996) Calcification in hermatypic and ahermatypic corals. Science 271:637-639

Editorial responsibility: Otto Kinne (Editor),

Oldendorf/Luhe, Germany
Muscatine L (1973) Nutrition of corals. In: Jones OA, Endean $\mathrm{R}$ (eds) Biology and geology of coral reefs. Academic Press, New York, p 77-115

Muscatine L, Porter JWP (1977) Reef corals: mutualistic symbioses adapted to nutrient-poor environments. Bioscience $27: 454-460$

Randall JE (1998) Zoogeography of shore fishes of the IndoPacific region. Zool Stud 37:227-268

Ridgway, SA, Reid DG, Taylor JD, Branch GM, Hodgson AN (1998) A cladistic phylogeny of the family Patellidae (Mollusca:Gastropoda). Philos Trans R Soc Lond B Ser B Biol Sci 353:1645-1671

Rowan R (1998) Diversity and ecology of zooxanthellae on coral reefs. J Phycol 34:407-417

Rowan R, Knowlton N (1995) Intraspecific diversity and ecological zonation in coral algal symbiosis. Proc Natl Acad Sci USA 92:2850-2853

Rowan R, Powers DA (1991) Molecular genetic identification of symbiotic dinoflagellates (zooxanthellae). Mar Ecol Prog Ser 71:65-73

Rowan R, Knowlton N, Baker A, Jara J (1997) Landscape ecology of algal symbionts creates variation in episodes of coral bleaching. Nature 388:265-269

Ryland JS (1997) Reproduction in Zoanthidea (Anthozoa: Hexacorallia). Invertebr Reprod Dev 31:177-188

Ryland JS, Muirhead A (1993) Order Zoanthidea. In: Mather P, Bennett I (eds) A coral reef handbook. Surry Beatty and Sons Pty, Chipping Norton, p 52-58

Ryland JS, de Putron S, Scheltema RS, Chimonides PJ, Zhadan DG (2000) Semper's (zoanthid) larvae: pelagic life, parentage and other problems. Hydrobiologia 440: 191-198

Schmidt H (1974) On evolution in the Anthozoa. Proc 2nd Int Coral Reef Symp 1:533-560

Sheppard CRC (1998) Biodiversity patterns in Indian Ocean corals, and effects of taxonomic error in data. Biodivers Conserv 7:847-868

Simon L, Lalonde M, Bruns TD (1992) Specific amplification of 18s fungal ribosomal genes from vesicular-arbuscular endomycorrhizal fungi colonizing roots. Appl Environ Microbiol 58:291-295

Smith DC, Douglas AE (1987) The biology of symbiosis. Arnold, London

Sorokin YI (1991) Biomass, metabolic rates and feeding of some common reef zoantharians and octocorals. Aust J Mar Freshw Res 42:729-741

Trench RK (1997) Diversity of symbiotic dinoflagellates and the evolution of microalgal-invertebrate symbioses. Proc 8th Int Coral Reef Symp 2:1275-1286

Veron JEN (1986) Corals of Australia and the Indo-Pacific. Angus and Robertson, North Ride

Williams ST, Benzie JAH (1998) Evidence of a biogeographic break between populations of a high dispersal starfish: congruent regions within the Indo-West Pacific defined by color morphs, mtDNA, and allozyme data. Evolution 52: $87-99$

Submitted: January 8, 2001, Accepted: July 24, 2001

Proofs received from author(s): May 14, 2002 